\title{
Pengaruh Pemberian Kurkumin Dalam Meringankan Gejala Delayed Onset Muscle Soreness (DOMS) Setelah Aktivitas Eksentrik
}

\author{
Reno Siska Sari ${ }^{1}$, Shinta Masitho $W^{2}$, Dinna Eka Graha Lestari ${ }^{3}$ \\ ${ }^{123}$ Fakultas Pendidikan Ilmu Eksakta dan Keolahragaan, Ikip Budi Utomo Malang \\ E-mail: renosiskasari@,budiutomomalang.ac.id ${ }^{1}$, \\ $\underline{\text { shintamasithowindriyani@budiutomomalang.ac.id }{ }^{2} \text {,dynna_lestari@yahoo.com }{ }^{3}}$
}

Menerima: 08 November 2020; Revisi: 10 Januari 2021; Diterima: 08 April 2021 Bi https://doi.org/10.24036/MensSana.06012021.15

\begin{abstract}
DOMS can cause pain and functional limitations such as stiffness and decreased strength which if not addressed properly, can adversely affect performance in sports activities. Symptoms are usually felt 12-24 hours after exercise and peak in 24-48 hours after exercise. The aim of the present study was to rapid DOMS recovery by knowing the effect of curcumin on reduction DOMS symptoms after eccentric exercise. The DOMS symptom measured was muscle pain.. The subjects were randomly divided into 2 groups, 18 people tried the treatment group (K1) and 18 people tried the control group (K2).Curcumin is given in capsule after eccentric activity at a dose of $150 \mathrm{mg}$. Curcumin was given 1, and 24 hours after eccentric activity. Muscle pain was measured by Visual Analogue Scale. Measurements were carried out 1, 24 and 48 hours (for 3 days) after the eccentric activity. The survey results revealed that administration of curcumin in the treatment group can reduce muscle pain at 48 hours after eccentric activity (5.08.3 \pm 0.79$)$ compared with the control group with $p=0.00(p<0.05)$.
\end{abstract}

Keywords: Eccentric activity, DOMS, muscle pain, curcumin

DOMS dapat menyebabkan nyeri otot dan keterbatasan fungsional seperti kekakuan dan penurunan pada kekuatan otot yang apabila tidak diatasi dengan benar dapat berdampak buruk pada peforma seseorang dalam melakukan aktivitas olahraga. Gejala yang dirasa biasanya 1224 jam setelah latihan dan mencapai puncaknya pada 24-48 jam setelah latihan.. Tujuan dari penelitian ini adalah mempercepat pemulihan DOMS dengan mengetahui pengaruh pemberian kurkumin dalam meringankan gejala DOMS setelah latihan eksentrik. Gejala DOMS yang diukur pada penelitian ini adalah nyeri otot. Desain penelitian ini adalah randomized group pretest and posttest design. Subjek penelitian dibagi secara acak ke dalam 2 kelompok, 18 orang coba kelompok perlakuan (K1) dan 18 orang coba kelompok kontrol (K2). Kurkumin diberikan dalam bentuk kapsul setelah aktivitas eksentrik dengan dosis $150 \mathrm{mg}$. Pemberian kurkumin dilakukan 1 jam dan 24 jam setelah aktivitas eksentrik. Nyeri otot diukur dengan Visual Analogue Scale. Pengukuran dilakukan 1, 24 dan 48 jam (selama 3 hari) setelah aktivitas eksentrik. Dari hasil penelitian diketahui bahwa pemberian kurkumin pada kelompok perlakuan dapat menurunkan nyeri otot pada 48 jam setelah aktivitas eksentrik $(5,08,3 \pm 0,79)$ jika dibandingkan dengan kelompok kontrol dengan nilai $\mathrm{p}=0,00(\mathrm{p}<0,05)$.

Kata kunci : Aktivitas eksentrik, DOMS, nyeri otot, kurkumin.

\section{PENDAHULUAN}

Delayed onset muscle soreness (DOMS) merupakan nyeri otot dan kekakuan yang dirasakan oleh seseorang setelah melakukan aktivitas olahraga (Zondi, 2015:29). DOMS menyebabkan kekakuan, bengkak, penurunan kekuatan dan nyeri pada otot. DOMS disadari dengan adanya rasa nyeri yang didapati 12-24 jam setelah olahraga dan mencapai puncaknya pada waktu 24-48 jam setelah olahraga (Szymanski, 2001:7). Menurut penelitian yang terdahulu, mekanisme terjadinya DOMS yang dialami seseorang disebabkan oleh latihan yang bersifat eccentric. 
Latihan eccentric merupakan latihan yang membutuhkan kontraksi otot yang memanjang dan memendek secara kuat. Hal ini ditunjukkan dengan sejumlah penelitian yang telah menguji tentang hubungan antara nyeri otot dan berbagai jenis latihan seperti latihan eccentric, concentric, dan aktivitas statis (Kim \& Lee, 2014:349). Telah diketahui bahwa DOMS adalah penyebab utama penurunan kinerja seorang atlet sehingga berpotensi mengganggu program latihan yang akan dijalankan maupun atlet yang akan bertanding (Contrò et al, 2016:1).

Salah satu solusi yang sering digunakan oleh atlet untuk mengatasi rasa nyeri tersebut adalah dengan mengkonsumsi obat-obatan antiinflamasi golongan nonsteroid atau yang lebih dikenal dengan non-steroidal antiinflammatory drugs (NSAIDs) untuk mengurangi atau mencegah nyeri pada otot selama pertandingan. NSAIDs bekerja dengan cara menghambat siklooksigenase yang berperann pada biosintesis prostaglandin yang merupakan mediator atau substansi radang.

Padahal, penggunaan NSAIDs dalam jangka panjang dapat mengakibatkan berbagai efek samping, yaitu gangguan saluran cerna, kerusakan pada ginjal, dan gangguan kardiovaskuler (Kuehl, 2010:1) Kurkumin adalah komponen dari tumbuhan kunyit (Curcuma longal Curcuma domestica) yang merupakan tumbuhan asli Indonesia, yang mudah didapat, murah dan banyak digunakan sebagai bahan baku obat tradisional. Kunyit termasuk dalam famili Zingiberaceae.

Kurikumin telah diketahui mempunyai banyak manfaat dalam dunia kesehatan yaitu efekanti inflamasi, antioksidan, hipokolesterolemik, hipolipidemik, hepatoprotektor, antikarsigogenik dan imunomodulator (Roihatul Mutiah, 2015:33). Menurut beberapa hasil penelitian sebelumnya, menyatakan bahwa kurkumin memiliki aktivitas antiinflamasi yang sama dengan beberapa obat antiinflamasi non-steroid (NSAIDs) seperti ibuprofen, dan celebrex akan tetapi tanpa adanya efek samping yang berlebihan seperti gangguan saluran cerna dan gangguan kardiovaskuler (Nakhostin-Roohi et al., 2016:26).

Kurkumin sendiri telah terdaftar pada dokumen Generally Recognized as Safe (GRAS) di Food and Drug Administration (FDA) Amerika (Gupta, 2013:200). Komponen aktiv yang terdapat pada kurkumin diketahui dapat menghambat sejumlah enzim proinflamasi seperti siklooksigenase dan lipoksigenase sehingga akan mengakibatkan penurunan pada sintesis prostaglandin dan. leukotrien yang berperan sebagai mediator radang (Noorafshan \& Ashkani-Esfahani, 2013:2033).

Beberapa penelitian sebelumnya melaporkan hasil yang bermanfaat untuk kurkumin sebagai bantuan untuk mempercepat pemulihan setelah latihan (Mallard, 2020:2). Pemberian kurkumin dalam jangka pendek (akut) dengan dosis $150 \mathrm{mg}$ setelah latihan eksentrik tidak hanya menjaga kapasitas respon antioksidan tetap tinggi, tetapi juga dapat mengurangi kerusakan otot yang disebabkan oleh DOMS (Nakhostin-Roohi, 2016:25)

Berdasarkan uraian di atas, maka penulis tertarik melakukan penelitian tentang pengaruh pemberian kurkumin dalam meringankan gejala DOMS (Delayaed Onset Muscle Soreness) setelah aktivitas eksentrik. Dalam penelitian ini penilaian gejala DOMS dilakukan dengan pengukuran nyeri otot. Tujuan dari penelitian ini adalah mempercepat pemulihan DOMS dengan mengetahui pengaruh pemberian kurkumin terhadap nyeri otot setelah latihan eksentrik.

\section{METODE PENELITIAN \\ 1. Jenis Penelitian}

Jenis penelitian yang akan dilakukan adalah penelitian eksperimental dengan desain penelitian Randomized group pre test and post test design.

\section{Populasi dan Subjek Penelitian}

Populasi dari penelitian ini adalah mahasisa PJKR IKIP Budi Utomo Malang. Subjek penelitianm laki-laki dengan kriteria inklusi usia 21-24 tahun, tidak sedang mengkonsumsi suplemen/ obat- obatan antiinflamasi, tidak melakukan aktivitas eksentrik menjelang penelitian (1minggu sebelumnya), tidak sedang cedera terutama pada tungkai ke bawah, IMT normal. Subjek berstatus sehat dan diseleksi dengan Physical Activity Readiness Questionnaire (PAR-Q) revisi 2002. Besar subjek didapatkan melalui rumus Federer.

Untuk penelitian eksperimen dengan rancangan acak lengkap, acak kelompok atau faktorial, secara sederhana dapat dirumuskan :

$$
\begin{aligned}
& (2-1)(\mathrm{r}-1) \geq 15 \\
& (2-1)(\mathrm{r}-1) \geq 15 \\
& \mathrm{r}-1 \quad \geq 15 \\
& \mathrm{r} \quad \geq 15 \\
& \text { Keterangan : }
\end{aligned}
$$


$\mathrm{t}=$ Jumlah Kelompok

$\mathrm{r}=$ Jumlah replikasi (sampel)

Jadi jumlah sampel minimum per kelompok adalah 16. Untuk menghindari kemungkinan orang coba drop out, (f) $\pm 10 \%$, sehingga : $10 / 100 \times 16=1,6=2$ (besar sampel dibulatkan). Jadi jumlah sampel adalah $16+2=18$ per kelompok dan keseluruhan sampel sebagai subjek penelitian adalah $18 \times 2=36$ orang coba.

\section{Bahan Penelitian}

Yang menjadi bahan dalam penelitian ini antara lain, air mineral, Kurkumin 150mg dalam bentuk tablet, dan sirup tanpa gula.

\section{Prosedur Pelaksanaan Penelitian}

Hari 1

1. Pemeriksaan kesehatan awal

2. Information for consent dan informed consent

3. Pengukuran awal nyeri dan kekuatan otot tungkai (pre test)

4. Diberikan sarapan pagi dengan jumlah dan jenis yang sama

5. Subjek melakukan aktivitas eksentrik ; drop jump sebanyak 10 set dan 10 repetisi dengan waktu recovery 1 menit diantara set (1 jam setelah sarapan).

6. Dilakukan pengukuran nyeri otot pada kedua kelompok penelitian (post test 1 )

7. Segera setelah post test 1 kelompok perlakuan diberikan kurkumin $150 \mathrm{mg}$ kelompok kontrol diberikan air sirup tanpa gula sebanyak $250 \mathrm{ml}$.

Hari 2

1. Pengukuran nyeri otot tungkai pada kedua kelompok penelitian pada 24 jam setelah aktivitas eksentrik (post test 2).

2. Segera setelah post tes 2, kelompok perlakuan diberikan kurkumin $150 \mathrm{mg}$, kelompok kontrol diberikan air sirup tanpa gula sebanyak $250 \mathrm{ml}$.

Hari 3

1. Pengukuran nyeri otot tungkai (post test 3)

Alat ukur yang digunakan untuk mengukur nyeri pada DOMS adalah Visual Analogue Scale (VAS) dengan provokasi nyeri tekan (Pearcey, 2015:6).Visual Analogue Scale (VAS) merupakan alat pengukuran intensitas nyeri yang dianggap paling efisien yang telah digunakan dalam penelitian dan pengaturan klinis.VAS umumnya disajikan dalam bentuk garis horisontal (Breivik, 2008:17). Dalam perkembangannya VAS menyerupai NRS (Numeric Rating Scale) yang cara penyajiannya diberikan angka $0-10 \mathrm{~cm} \quad(0-100 \mathrm{~mm})$ yang masing-masing nomor dapat menunjukkan intensitas nyeri yang dirasakan oleh pasien.

VAS dinilai dengan kata tidak nyeri di ujung kiri dan sangat nyeri di ujung kanan. Dinilai tidak ada nyeri apabila nilai VAS 0$44 \mathrm{~mm}$, nyeri ringan apabila panjang garis menunjukkan angka $5-44 \mathrm{~mm}$, 45-74mm dinyatakan sebagai nyeri sedang, dan $75-10 \mathrm{~mm}$ dinilai sebagai nyeri berat (Hawker, 2011:240241). Prosedur pelaksanaannya subjek duduk dengan nyaman, fisioterapis memberikan penekanan dengan jari pada otot yang akan dihitung.Kemudian fisioter apis menanyakan derajat nyeri kepada subjek untuk dicatat menggunakan skala nyeri 0 sampai dengan 10 .

\section{Teknik Analisis Data}

Analisis data dilakukan dengan menggunakan bantuan program SPSS seri 20 dengan derajat signifikansi sebesar 95\%

1. Uji statistik deskriptif

2. Uji normalitas

3. Uji T 2 sampel bebas.

\section{HASIL PENELITIAN}

\section{Hasil Deskriptif Nyeri Otot}

Hasil analisis deskriptif berupa rerata dan simpangan baku tingkat nyeri otot tungkai pre test, post test1, post test 2, post test 3 subjek penelitian pada kelompok perlakuan (K1) dan kelompok kontrol (K2) dapat dilihat pada tabel dibawah ini; 
Pengaruh Pemberian Kurkumin Dalam Meringankan Gejala Delayed Onset Muscle Soreness (DOMS) Setelah Aktivitas Eksentrik.

Reno Siska Sari ${ }^{1}$, Shinta Masitho $W^{2}$, Dinna Eka Graha Lestari ${ }^{3}$

Tabel 1 Hasil Deskriptif Nyeri Otot

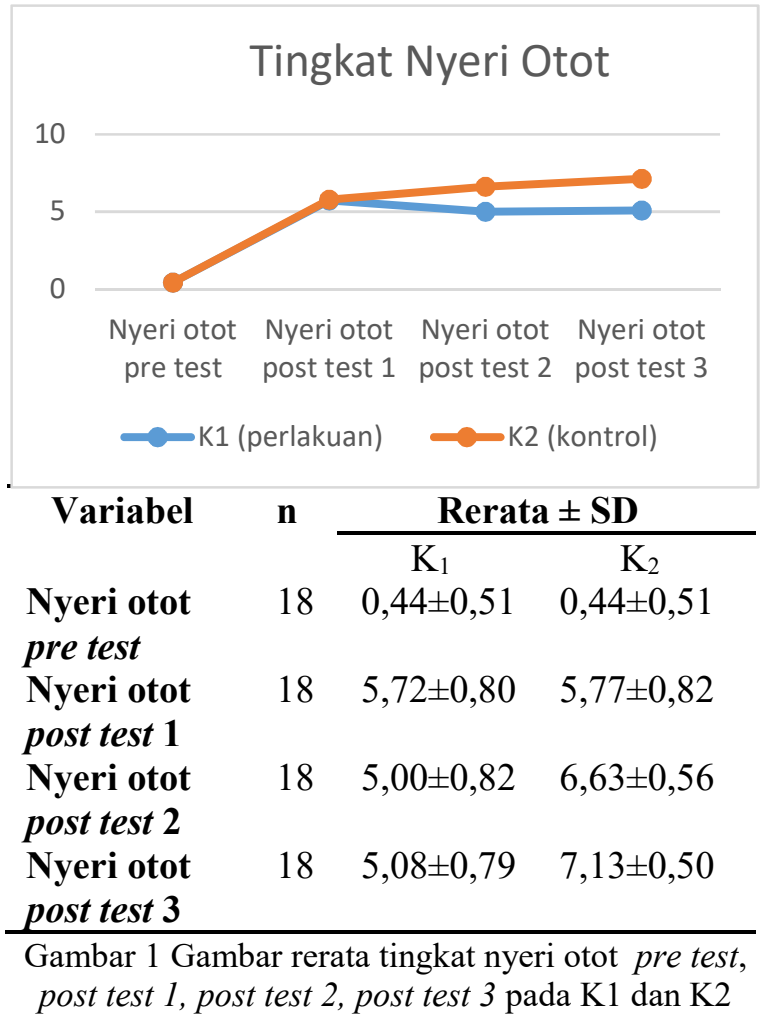

\section{Hasil Uji Normalitas Nyeri Otot}

Hasil uji normalitas variable tingkat nyeri otot kedua kelompok disajikan pada tabel berikut dan hasilnya menunjukkan pada semua kelompok datanya berdistribusi normal dengan nilai $\mathrm{p}>0,05$. Tabel 2 Hasil Uji Normalitas Nyeri Otot

\section{Hasil Uji t 2 Sampel Bebas}

Data penelitian yang telah memenuhi syarat normalitas selanjutnya data dianalisis dengan uji t 2 sampel bebas. Data pada variabel dikatakan memiliki perbedaan yang bermakna apabila nilai uji $\mathrm{p}<0,05$.

Hasil analisis menunjukkan nilai nyeri otot antara kelompok kontrol dan kelompok perlakuan berbeda bermakna dengan nilai $p=0,00$. Hasil uji t 2 sampel bebas dapat dilihat pada tabel dibawah ini

Tabel 3 Hasil Uji 2 Sampel Bebas Nyeri Otot

\begin{tabular}{lc}
\hline \multicolumn{1}{c}{ Variabel } & $\begin{array}{c}\text { p-value } \\
\text { Nyeri Otot }\end{array}$ \\
\hline $\begin{array}{l}\Delta \text { post test } 3-\text { pre test } K_{1} \\
\text { dan } K_{2}\end{array}$ & 0,00 \\
\hline
\end{tabular}

\section{Pembahasan}

Hasil penelitian menunjukkan bahwa test) pada kedua kelompok dikatakan dalam kategori normal/tidak nyeri yaitu dengan rerata sebesar

\begin{tabular}{ccccc}
\hline Kelompok & \multicolumn{4}{c}{ Nilai p nyeri otot } \\
\cline { 2 - 5 } & Pre & Post 1 & Post 2 & Post 3 \\
$\mathbf{K}_{\mathbf{1}}$ & 0,07 & 0,82 & 0,33 & 0,84 \\
$\mathbf{K}_{\mathbf{2}}$ & 0,08 & 0,36 & 0,09 & 0,31 \\
\hline
\end{tabular}

$0,44 \pm 0.51$ pada $\mathrm{K}_{1}$ dan $0,44 \pm 0,51$ pada $\mathrm{K}_{2}$. Dinilai tidak ada nyeri apabila nilai VAS $0-4 \mathrm{~mm}$ (Hawker, 2011:240). Kondisidemikian memberikan suatu gambaran bahwa keadaan tingkat nyeri otot awal pada kedua kelompok mempunyai nilai yang sama.

Rerata tingkat nyeri otot pada saat 1 jam (post test 1), 24 jam (post test 2), 48 jam (post test 3) pada kedua kelompok menunjukkan peningkatan tingkat nyeri otot jika dibandingkan dengan rerata tingkat nyeri otot pre test pada masing- masing kelompok dan dikatakan berada dalam tingkat nyeri sedang, yaitu skala 45$77 \mathrm{~mm}$. Hal ini menunjukkan bahwa aktivitas eksentrik yang diberikan dapat menyebabkan nyeri otot pada masing- masing kelompok.

Nyeri otot yang dirasa oleh kedua kelompok ini dipicu oleh DOMS (Delayed Onset Muscle Soreness). DOMS merupakan kombinasi rasa nyeri dan kekakuan pada otot yang terjadi beberapa jam setelah latihan yang tidak terbiasa terutama latihan yang melibatkan kontraksi ekesentrik (Drobnic, 2014:2). Pada umumnya DOMS terus meningkat setelah latihan dan puncaknya antara 24 - 48 jam setelah latihan (Contrò , 2016:121).

Terjadinya DOMS akan direspon tubuh dengan melakukan inflamasi sebagai upaya awal untuk memulai proses penyembuhan. Kejadian inflamasi ditandai dengan adanya rangsangan nyeri yang dirasakan penderita (Rakasiwi, 2014:27). Rasa nyeri diakibatkan oleh adanya respon inflamasi. Olahraga mengakibatkan terjadinya trauma mikro, dalam hal ini adalah kerusakan pada otot yang bersifat akut. Kerusakan otot tersebut akan memicu 
pelepasan sitokin, melokalisir edema karena migrasi monosit, makrofag, prostaglandin, histamin, dan lain-lain. Peningkatan edema dan pelepasan prostaglandin serta histamin berperan dalam timbulnya rasa nyeri yang merupakan salah satu bukti dari kerusakan otot (Eston, 2004:92)

Hasil uji statistik menunjukkan perbedaan yang bermakna pada tingkat nyeri otot antara kelompok perlakuan $\left(\mathrm{K}_{1}\right)$ dan kontrol $\left(\mathrm{K}_{2}\right)$ pada 48 jam setelah aktivitas eksentrik. Perbedaan yang bermakna tersebut diduga oleh karena pemberian kurkumin yang diberikan pada 1 jam dan 24 jam setelah aktivitas eksentrik pada kelompok perlakuan. Selama ini atlet mengatasi rasa nyeri dengan mengkonsumsi NSAIDs yang bekerja dengan cara menghambat siklooksigenase yang berperan pada biosintesis prostaglandin yang merupakan mediator atau substansi radang.

Penggunaan NSAIDs dalam jangka panjang dapat mengakibatkan berbagai efek samping, yaitu gangguan saluran cerna, kerusakan pada ginjal, dan gangguan kardiovaskuler (Kuehl et al., 2010:1). Kurkumin memiliki aktivitas antiinflamasi yang sama dengan beberapa obat antiinflamasi non-steroid (NSAIDs) seperti ibuprofen, dan celebrex akan tetapi tanpa adanya efek samping yang berlebihan seperti gannguan saluran cerna dan gangguan kardiovaskuler (NakhostinRoohi,2016:26).

Komponen aktiv yang terdapat pada kurkumin diketahui dapat menghambat sejumlah enzim proinflamasi seperti siklooksigenase dan lipoksigenase sehingga akan mengakibatkan penurunan pada sintesis prostaglandin dan leukotrien yang berperan sebagai mediator inflamasi (Nicol, 2015:1774). Efek analgesik dari kurkumin didapatkan karena kurkumin memiliki efek memblok NF-kB dan menekan Cyclooxygenase-2 (COX-2).

Sehingga menghasilkan pengurangan pada nyeri otot (Tanabe, 2015:1956). Penghambatan aktivitas enzim siklooksigenase akan mengakibatkan penurunan pembentukan prostaglandin, penghambatan sintesis leukotrien, penghambatan produksi interleukin dan TNF $\alpha$ dalam mengaktivasi makrofag (McFarlin, 2016:76). Penurunan pembentukan prostaglandin dan leukotrien inilah yang akan mengurangi nyeri (Astuti \& Murbawani, 2011: 15)
Selain memiliki sifat antiinflamasi kurkumin juga memiliki sifat antioksidan yang secara tidak langsung bereperan dalam mengurangi nyeri. Senyawa fenol yang terdapat pada kurkumin bertindak sebagai antioksidan karena kemampuannya dalam menstabilkan radikal bebas, yaitu dengan menghambat peroksidasi lipid (Zondi, 2015:28). Kerusakan otot dapat disebabkan oleh produksi radikal bebas sebagai respon terhadap olahraga yang melelahkan sehingga menyebabkan peningkatan inflamasi (peradangan), nyeri dan penurunan kinerja otot (Davis, 2007:168).

Salah satu mekanisme dalam mengurangi peradangan adalah dengan menstabilkan atau menetralisir radikal bebas. Proses peradangan akan melepaskan makrofag sebagai respon peradangan. Makrofag yang dilepaskan akan menghasilkan ROS yang akan memperbesar kerusakan otot dan meningkatkan rasa nyeri. ROS dapat dinetralisir dengan konsumsi antioksidan. Penetralisiran ROS akan menurunkan kerusakan otot dan mengurangi nyeri otot (Astuti \& Murbawani, 2011:15).

Laporan pada studi lain mengatakan bahwa kurkumin menunjukkan aktivitas antioksidan yang kuat se banding dengan vitamin C dan vitamin E (Drobnic, 2014:3). Penelitian yang dilakukan oleh Di Pierro melaporkan bahwa pemberian kurkumin 400mg memiliki efek penghilang rasa sakit, bahkan lebih besar dari acetaminophen 500mg (Di Pierro, 2013:13 ). Hasil penelitian lainnya juga menunjukkan suplementasi kurkumin menyebabkan penurunan pada nyeri otot yang dipicu oleh DOMS (Drobnic, 2014:1)

\section{KESIMPULAN}

Pada penelitian ini didapatkan bahwa, kurkumin efektif dalam mempercepat pemulihan DOMS ditandai dengan adanya penurunan nyeri otot yang bermakna pada kelompok perlakuan (K1) pada 48 jam setelah aktivitas eksentrik. Keterbatasan pada penelitian ini adalah tidak dilakukannya uji laboratorium terhadap serum biomarker peradangan seperti prostagla seperti prostaglandin dan leukotriene.

Selain itu kesulitan untuk menyamakan kegiatan dan makanan yang dikonsumsi subyek 
Pengaruh Pemberian Kurkumin Dalam Meringankan Gejala Delayed Onset Muscle Soreness (DOMS) Setelah Aktivitas Eksentrik.

Reno Siska Sari ${ }^{1}$, Shinta Masitho $W^{2}$, Dinna Eka Graha Lestari ${ }^{3}$

penelitian, karena ditakutkan dapat Eston, R., Byrne, C., \& Twist, C. (2004).

mempengaruhi hasil peneliti.

Muscle function after exercise-induced muscle damage: Considerations for athletic performance in children and adults.

\section{DAFTAR PUSTAKA}

Astuti, A. D. W., \& Murbawani, E. A. (2011).

Efektivitas Pemberian Ekstrak Jahe Merah

( Zingiber officinale roscoe varr Rubrum ) dalam Mengurangi Nyeri Otot pada Atlet. Artikel Penelitian Program Studi Ilmu Gizi Fakultas Kedokteran Universitas

Diponegoro, 1-29.

http://eprints.undip.ac.id/32557/1/381_Am bar_Dwi_Widhi_Astuti_G2C007006.pdf

Breivik, H., Borchgrevink, P. C., Allen, S. M., Rosseland, L. A., Romundstad, L., Breivik Hals, E. K., Kvarstein, G., \& Stubhaug, A. (2008). Assessment of pain. British Journal of Anaesthesia, 101(1), 17-24. https://doi.org/10.1093/bja/aen103

Contrò, V., Mancuso, E., \& Proia, P. (2016). Delayed onset muscle soreness (DOMS) management: present state of the art. Trends in Sport Sciences, 23(3), 121-127.

Davis, J. M., Murphy, E. A., Carmichael, M. D., Zielinski, M. R., Groschwitz, C. M., Brown, A. S., Gangemi, J. D., Ghaffar, A., \& Mayer, E. P. (2007). Curcumin effects on inflammation and performance recovery following eccentric exercise-induced muscle damage. American Journal of Physiology - Regulatory Integrative and Comparative Physiology, 292(6), 21682173. https://doi.org/10.1152/ajpregu.00858.200 6

Di Pierro, F., Rapacioli, G., Di Maio, E. A., Appendino, G., Franceschi, F., \& Togni, S. (2013). Comparative evaluation of the pain-relieving properties of a lecithinized formulation of curcumin (Meriva ${ }^{\circledR}$ ), nimesulide, and acetaminophen. Journal of Pain Research, 6, 201-205. https://doi.org/10.2147/JPR.S42184

Drobnic, F., Riera, J., Appendino, G., Togni, S., Franceschi, F., Valle, X., Pons, A., \& Tur, J. (2014). reduction of delayed muscle soreness- cucurmin-A.Elliott. Journal of the International Society of Sports Nutrition, 11, 1-10. Journal of Exercise Science and Fitness, 1(2), 85-96.

Gupta, S. C., Patchva, S., \& Aggarwal, B. B. (2013). Therapeutic roles of curcumin: Lessons learned from clinical trials. AAPS Journal, 15(1), 195-218. https://doi.org/10.1208/s12248-012-9432-8

Hawker, G. A., Mian, S., Kendzerska, T., \& French, M. (2011). Measures of adult pain: Visual Analog Scale for Pain (VAS Pain), Numeric Rating Scale for Pain (NRS Pain), McGill Pain Questionnaire (MPQ), Short-Form McGill Pain Questionnaire (SF-MPQ), Chronic Pain Grade Scale (CPGS), Short Form-36 Bodily Pain Scale (SF. Arthritis Care and Research, 63(SUPPL. 11), 240-252.

https://doi.org/10.1002/acr.20543

Kim, J., \& Lee, J. (2014). A review of nutritional intervention on delayed onset muscle soreness. Part I. Journal of Exercise Rehabilitation, 10(6), 349-356. https://doi.org/10.12965/jer.140179

Kuehl, K. S., Perrier, E. T., Elliot, D. L., \& Chesnutt, J. C. (2010). Efficacy of tart cherry juice in reducing muscle pain during running: A randomized controlled trial. Journal of the International Society of Sports Nutrition, 7, 1-6. https://doi.org/10.1186/1550-2783-7-17

Mallard, A. R., Briskey, D., Richards, BExSSc, A., \& Rao, A. (2020). Curcumin Improves Delayed Onset Muscle Soreness and Postexercise Lactate Accumulation. Journal of Dietary Supplements, O(0), 112. https://doi.org/10.1080/19390211.2020.17 96885

McFarlin, B. K., Venable, A. S., Henning, A. L., Sampson, J. N. B., Pennel, K., Vingren, J. L., \& Hill, D. W. (2016). Reduced inflammatory and muscle damage biomarkers following oral supplementation with bioavailable curcumin. BBA Clinical, $5,72-78$. 
https://doi.org/10.1016/j.bbacli.2016.02.00 3

Nakhostin-Roohi, B., Nasirvand Moradlou, A., Mahmoodi Hamidabad, S., \& Ghanivand, B. (2016). The Effect of Curcumin Supplementation on Selected Markers of Delayed Onset Muscle Soreness (DOMS). Annals of Applied Sport Science, 4(2), 25 31.

https://doi.org/10.18869/acadpub.aassjourn al.4.2.25

Nicol, L. M., Rowlands, D. S., Fazakerly, R., \& Kellett, J. (2015). Curcumin supplementation likely attenuates delayed onset muscle soreness (DOMS). European Journal of Applied Physiology, 115(8), 1769-1777.

https://doi.org/10.1007/s00421-015-3152-6

Noorafshan, A., \& Ashkani-Esfahani, S. (2013). A Review of Therapeutic Effects of Curcumin. Current Pharmaceutical Design, 19(11), 2032-2046. https://doi.org/10.2174/138161281131911 0006

Pearcey, G. E. P., Bradbury-Squires, D. J., Kawamoto, J. E., Drinkwater, E. J., Behm, D. G., \& Button, D. C. (2015). Foam rolling for delayed-onset muscle soreness and recovery of dynamic performance measures. Journal of Athletic Training, 50(1), 5-13. https://doi.org/10.4085/10626050-50.1.01

Rakasiwi, A. M. (2014). Aplikasi Ice Massage Sesudah Pelatihan Lebih Baik Ice Massage Pada Otot Hamstring. Jakarta : Universitas Esa Unggul, 14(April). http://id.portalgaruda.org/?ref=browse \&mo $\mathrm{d}=$ viewjournal\&journal $=4571$

Roihatul Mutiah. (2015). EVIDENCE BASED KURKUMIN DARI TANAMAN
KUNYIT (Curcuma longa) SEBAGAI

TERAPI KANKER PADA

PENGOBATAN MODERN. Jurnal

Farma Sains, 1(1), 28-41.

Szymanski, D. J. (2001). Recommendations for the Avoidance of Delayed-Onset Muscle Soreness. Strength and Conditioning Journal, 23(4), 7-13.

https://doi.org/10.1519/00126548-

200108000-00001

Tanabe, Y., Maeda, S., Akazawa, N., ZempoMiyaki, A., Choi, Y., Ra, S. G., Imaizumi, A., Otsuka, Y., \& Nosaka, K. (2015).

Attenuation of indirect markers of eccentric exercise-induced muscle damage by curcumin. European Journal of Applied Physiology, 115(9), 1949-1957.

https://doi.org/10.1007/s00421-015-3170-4

Zondi, P. C., Janse van Rensburg, D. C., Grant, C. C., \& Jansen van Rensburg, A. (2015). Delayed onset muscle soreness: No pain, no gain? The truth behind this adage. South African Family Practice, 57(3), 29-33. https://doi.org/10.4102/safp.v57i3.4148 